\title{
The impact of closed depressions on soil organic carbon storage in eroded loess landscapes of E Poland
}

\author{
Renata Kołodyńska-Gawrysiak ${ }^{1}$, Leszek Gawrysiak ${ }^{2}$, Jean Poesen $^{3}$, and Andrzej Plak ${ }^{2}$ \\ ${ }^{1}$ Maria Curie-Sklodowska University \\ ${ }^{2}$ Maria Curie-Sklodowska University in Lublin Faculty of Earth Science and Spatial \\ Management \\ ${ }^{3} \mathrm{KU}$ Leuven
}

July 9,2021

\begin{abstract}
Soil erosion is an important problem in the loess landscapes of Europe, resulting in a lowering of soil quality and landscape changes. As a result of soil erosion, SOC is redistributed and stored in SOC pools within the landscape. Understanding the SOC dynamics is important because changes in the SOC stocks may have large impacts on global climate change. Closed depressions (CDs) in loess landscapes collect colluvial sediments resulting from soil erosion and constitute sediment stores enabling the calculation of soil erosion phases and rates. CDs are also SOC pools enabling assessing of SOC erosion and storage in loess landscapes over long periods. Colluvial sediments and fossil soils, infilling five representative CDs in the Polish loess areas used for agriculture during several millennia, were documented. The mean SOC content in CDs were calculated, the area of CDs at the regional scale were mapped. Between 11.66 and $31.78 \mathrm{Mg}$ of SOC are stored in each CD. The SOC within CDs represents a significant SOC storage in the landscape of the studied region and can reach values between 178.96 and $206.73 \mathrm{Mg} \cdot \mathrm{ha}-1$ (mean 192.85 Mg.ha-1), the SOC content in the soil cover of the surrounding eroded slopes and plateaus is $102.38 \mathrm{Mg} \cdot \mathrm{ha}-1$. This study indicates that CDs are a key morphological features for a better understanding of the spatial distribution of SOC in agricultural used loess landscapes of eastern Poland. SOC storage in CDs needs to be taken into account when calculating total soil carbon storage at the regional scale.
\end{abstract}

The impact of closed depressions on soil organic carbon storage in eroded loess landscapes of E Poland

Kołodyńska-Gawrysiak Renata ${ }^{1}$, Gawrysiak Leszek ${ }^{1}$, Poesen Jean ${ }^{1,2}$, Plak Andrzej ${ }^{1}$

${ }^{1}$ Faculty of Earth Science and Spatial Management Maria Curie-Skłodowska University

in Lublin

${ }^{2}$ Department of Earth and Environmental Science, KU Leuven University

Corresponding Author: renata.kolodynska-gawrysiak@poczta.umcs.lublin.pl

Soil erosion is an important problem in the loess landscapes of Europe, resulting in a lowering of soil quality and landscape changes. As a result of soil erosion, SOC is redistributed and stored in SOC pools within the landscape. Understanding the SOC dynamics is important because changes in the SOC stocks may have large impacts on global climate change. Closed depressions (CDs) in loess landscapes collect colluvial sediments resulting from soil erosion and constitute sediment stores enabling the calculation of soil erosion phases and rates. CDs are also SOC pools enabling assessing of SOC erosion and storage in loess landscapes over long periods. 
Colluvial sediments and fossil soils, infilling five representative CDs in the Polish loess areas used for agriculture during several millennia, were documented. The mean SOC content in CDs were calculated, the area of $\mathrm{CDs}$ at the regional scale were mapped.

Between 11.66 and $31.78 \mathrm{Mg}$ of SOC are stored in each CD. The SOC within CDs represents a significant SOC storage in the landscape of the studied region and can reach values between 178.96 and $206.73 \mathrm{Mg} \cdot \mathrm{ha}^{-1}$ (mean $\left.192.85 \mathrm{Mg} \cdot \mathrm{ha}^{-1}\right)$, the SOC content in the soil cover of the surrounding eroded slopes and plateaus is 102.38 $\mathrm{Mg} \cdot \mathrm{ha}^{-1}$.

This study indicates that CDs are a key morphological features for a better understanding of the spatial distribution of SOC in agricultural used loess landscapes of eastern Poland. SOC storage in CDs needs to be taken into account when calculating total soil carbon storage at the regional scale.

Keywords: SOC storage, loess landscape, closed depressions, soil erosion, colluvial sediments, fossil soils

\section{Introduction}

Soil organic carbon (SOC) represents the largest part of the terrestrial carbon reservoir (Doetterl et al., 2016).

SOC determines qualities and functions of soils and is partly released into the atmosphere possibly contributing to climate change (e.g. Batjes, 1996; Lal, 2004; Meersmans et al., 2016; Wiesmeier et al., 2019). Quantification of soil organic carbon storage at various spatial and temporal scales is important in the context of climate and environmental changes as well as land management. Current regional studies have used a multiple regression approach to predict SOC (e.g. Grimm et al., 2008; Meersmans et al., 2008; Suuster et al., 2012).

Wiesmeier et al., (2019) proposed a quantification of SOC storage using many different indicators based on mainly factors controlling SOC content in soils.

Soil types and its features (i.e. clay content, soil texture, $\mathrm{Ca}$ and $\mathrm{Mg}$ cations, metal oxides, micro and macro soil fauna), soil moisture (drainage class), climate (air temperature, precipitation, potential evapotranspiration), topography (slope gradient, elevation and other terrain attributes) and land use are factors most often used for SOC assessment, as well as for mapping and predicting SOC distribution (e.g. Tan et al., 2004; Vos et al., 2019; Wiesmeier et al., 2014; Wiesmeier et al., 2019). However, it should be emphasized that SOC content also changes with soil depth depending on different controlling factors (e.g. Hobley \& Wilson, 2016; Jobbágy \& Jackson, 2000; Vos et al., 2019). The SOC content is most frequently studied in the topsoil (i.e. the upper 0.15-0.3 m), and rarely in the entire soil profiles (e.g. Arrouays et al., 2001, Bellamy et al., 2005; Pignard et al., 2000; Rumpel \& Kögel-Knabner, 2011; van Wesemael et al., 2005).

Rumpel \& Kögel-Knabner, (2011) suggest that ca. 50\% of the total SOC stocks is found in subsoil. Especially in eroded landscapes SOC buried at depositional sites may be underestimated when one assesses SOC stocks in topsoil only. Therefore, SOC content in the entire soil profile should be assessed (Doetterl et al., 2016).

In landscapes where significant soil erosion occurs, the importance of topographic conditions for the spatial distribution of SOC and its storage is emphasized (Doetterl et al., 2016).

Some studies revealed that topographical features are of major importance for understanding SOC distribution only at local scales where there are small variations in soil properties. At regional scale topography is usually considered to be less important for SOC storage (e.g. Thompson et al., 2006; Vos et al., 2019). Soil moisture (low $\mathrm{C}$ mineralization and microbial activity under high soil moisture content) is considered to be the most important factor for SOC storage and its spatial distribution at regional scale (e.g. Neufeldt, 2005; Tan et al., 2004; Wiesmeier et al., 2019).

It should be noted, however, that the spatial variation of soil moisture content is affected by the topography of an area. The presence of concave forms, small elevation differences and gentle slopes favour the retention of soil moisture, while steep slopes and large elevation differences are conducive to the drainage of surface 
and subsurface water rather than the retention of moisture in the soil. Therefore, topography is a significant factor and may have not only a direct (SOC erosion control) but also an indirect (moisture control) effect on SOC distribution in landscapes.

The models predicting SOC dynamics are often used at regional and national scales. Martin et al. (2014) compared and evaluated available models used for SOC stocks prediction and mapping.

In previous studies it was observed that some landscapes in loess regions may have up to 60 CDs per $\mathrm{km}^{2}$ closed depressions (CDs) in which colluvial deposits containing SOC have been reported (KołodyńskaGawrysiak \& Poesen, 2017; Kołodyńska-Gawrysiak, Poesen \& Gawrysiak, 2018). The aim of this study is therefore to quantitatively assess the influence of such CDs on the spatial SOC distribution in eroded loess landscapes at the regional scale. This study addresses SOC across the whole soil profiles.

\section{Materials and methods}

\subsection{Study area}

The study area is the Nałęczów Plateau (East Poland) which covers 49608 ha (Figure 1).

The area is covered by loess patches which were mainly deposited during the Vistulian Glaciation ( ca. 50 $000 \mathrm{BP}$ to $15000 / 12000 \mathrm{BP}$ ). These loess patches are separated by river valleys where the loess cover is absent (Maruszczak, 1991). The thickness of the loess reaches values of 10 to $20 \mathrm{~m}$ in the eastern part and up to $30 \mathrm{~m}$ in the western part of the region (Harasimiuk, 1987).

Peat with a mean thickness of $3 \mathrm{~m}$, covered by alluvial soils with a mean thickness of $2.3 \mathrm{~m}$, is found in the river valleys of the study area (e.g. Bałaga \& Maruszczak, 1981; Urban \& Mikosz, 1996; Superson et al., 2003, 2016).

The loess belt covers a Pleistocene sediment complex made up of glacigenic deposits (glacial tills, sands and gravels, clayey loams, clays) from the Odranian (Saale 1) and the Sanian (Elsterian) Glaciation (Harasimiuk \& Henkiel, 1978; Pożaryski et al., 1994). The bedrock of the Nałęczów Plateau consists of Upper Maastrichtian (opoka, marly opoka, marl) and Palaeogene (limestone, gaize and carbonate sandstone) rocks (Pożaryska, 1967; Harasimiuk, 1980).

Vast surfaces of this loess plateau have CDs that are a typical element of the landscape of the Nałęczów Plateau (Figure 1). CDs are shallow and barely visible in loess landscape micro landforms, infilled by soilsediment sequences (Figure 2). Moreover, the Nałęczów Plateau is dissected by main river valleys (Bystra, Ciemięga) and also small river valleys (Grodarz, Czechówka) as well as many erosion-denudation valleys and gully systems (Figure 1). The average density of the gully network is $2.48-10 \mathrm{~km}$ per $\mathrm{km}^{2}$ in the western part of the region, while in the eastern part it does not exceed $2 \mathrm{~km}$ per $\mathrm{km}^{2}$ (Gawrysiak \& Harasimiuk, 2012). The relative heights in the region reach $40-50 \mathrm{~m}$ and maximally $90 \mathrm{~m}$ in the western part of the region.

The loess of the Nałęczów Plateau is overlain by Luvisols in different stages of erosion, Colluvisols in CDs and dry valley bottoms as well as Fluvisols in valley bottoms.

\subsection{Soil data}

\subsection{Field and sampling methods}

5 CDs, representative for this study area, were chosen for detailed soil profile and SOC measurements. At the bottom of each CD (i.e. its deepest point), a 160-220 cm deep soil profile pit (outcrop) was dug, reaching the lower boundary of the soil horizons (Figure 3). Next, identification and documentation of soil horizons and colluvial layers in the exposures were made. All outcrops were described, according to standard methods (Guidelines for soil descriptions, FAO, 2006).

Bulk samples of soils and sediments were collected from each horizon in the wall of the exposures for laboratory analysis. One to four samples were collected from each of the horizons distinguished, depending on their thickness. 
A total of 103 soil samples were collected from 5 soil profiles, all located in the bottom of the studied CDs. The samples were air-dried, crushed with a mortar, sieved at $2 \mathrm{~mm}$ and stored in plastic bags.

Furthermore, 20 to 30 control augerings were carried out in each CD to determine the areal extent and thickness of colluvial sediments (C1, C2) and fossil soil horizon (A, Bh, Bt) extension. Augerings were located in two cross-sections of each CD (Figure 3).

\subsubsection{Laboratory analyses and SOC stock calculations}

Soil organic carbon content (SOC \%) was determined using a LECO CNS elementary analyzer. The calibration method was based on ISO 10694:2002 and was three-point calibration with the transition through point 0. C: $\mathrm{y}=0.9904 \mathrm{x}+0.0051$. Mean SOC (mass \%) was calculated for the sampled soil horizons. SOC content in the CDs (SOC cont, t) was calculated using the volume $\left(\mathrm{V}, \mathrm{m}^{3}\right)$ of colluvial layers and fossil soil horizons as well as bulk density $\left(\mathrm{B}, \mathrm{t} \cdot \mathrm{m}^{3}\right)$. The volume $\left(\mathrm{V}, \mathrm{m}^{3}\right)$ of colluvial layers and fossil soil horizons was determined as the product of the areal extent $\left(\mathrm{E}, \mathrm{m}^{2}\right)$ of the colluvial layers and the fossil soil horizons and the mean thickness $(\mathrm{D}, \mathrm{m})$ of these layers : $\mathrm{V}=\mathrm{E} \times \mathrm{D}$;

SOC cont $=\mathrm{V} \times \mathrm{B} \times \operatorname{SOC}(\%)$.

SOC content in the soil covering the loess plateau and slopes in the studied region was estimated using data from soil profiles studied by Paluszek (2001) and Paluszek, Żembrowski (2008).

\subsection{Delimitation of closed depressions and map elaboration methodology}

The analysis of closed depressions was made using a Digital Terrain Model (DTM) elaborated as a part of the ISOK project (Informatic System for Country Protection against extraordinary hazards), involving LiDAR scanning of Poland in the period 2011-2014 (Woźniak, 2015). The DTM has a vertical accuracy of $0.15 \mathrm{~m}$ and a high spatial resolution of $1 \mathrm{x} 1 \mathrm{~m}$ (Kurczyński et al., 2015). Closed depressions were extracted from this DTM using the CDs function, included in SAGA-GIS (Conrad et al., 2015). The resulting grid contained all CDs, strongly differentiated in shape and size. In the next stage, depressions with an area of more than $200 \mathrm{~m}^{2}$ were extracted and grid data was converted to shapefile polygons. Then depressions of anthropogenic origin were manually selected and removed based on the analysis of shaded relief, coloured DTM and field observations. Next, polygons were automatically smoothed and small errors were manually removed from some polygons. The spatial distribution of SOC was analysed using 10 ha hexagons. First, a simplified geomorphological map of the Nałęczów Plateau, containing the valley bottoms, slopes, plateaus and closed depressions, was drawn using GIS software. Then data from laboratory analyses of SOC content in the soils inside the CDs were assigned to their map polygons, while SOC content in soils outside CDs in the study area was obtained from published data and assigned to the polygons as well. Then the contribution (\%) of the main relief elements (CDs, slopes and hilltops) inside each hexagon was calculated. Based on the SOC content of these relief elements, total SOC content within the hexagons were computed. Only hexagons where CDs, slopes and tops cover together entirely hexagons's area were used in calculations. Separate maps of SOC content within the closed depressions and of closed depressions together with plateaus and slopes were elaborated. Hexagons of 10 ha area were used for the spatial analysis of the CDs in the study area (consisting of 4960 hexagons). The number of CDs per unit area (density of CDs) in the study area was calculated by summing all CDs per hexagon and then converting these values into the number of CDs per ha.

For the calculation of the spatial distribution of SOC in the eroded loess landscape, measured SOC content in CDs and on slopes were used. SOC values for each hexagon are calculated as sum of SOC content in all the corresponding CDs and the SOC content of the remaining sloping areas. These calculations cover $100 \%$ of the Nałęczów Plateau. SOC present in valley bottoms was not taken into account in these calculations.

For calculating SOC from all CDs in the study area only the areal fraction of the CDs in each hexagon was taken into account. This calculation covers 23010 ha (46.3\% of the Nałęczów Plateau). Contribution of SOC stored in CDs (SOC enrichment in $\mathrm{Mg} \cdot \mathrm{ha}^{-1}$ ) to overall SOC distribution in the studied landscape was calculated as the difference between SOC content in CDs and the SOC content on slopes. 


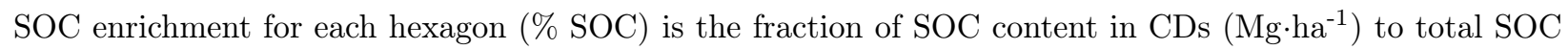
content in CDs and on slopes. This calculation is only made for hexagons, where CDs and slopes cover together 100\% of the hexagon area (in total 19820 ha, $39.95 \%$ of the Nałęczów Plateau).

Next Pearsons' correlation coefficients were calculated between the density of CDs and SOC enrichment $\left(\mathrm{Mg} \cdot \mathrm{ha}^{-1}\right.$ and \%) per hexagon.

\section{Results}

\section{1. Spatial distribution and structure of closed depressions (CDs)}

CDs are small landforms, commonly found in the European loess belt (Kołodyńska-Gawrysiak \& Poesen, 2017). 5367 CDs have been mapped in the Nałęczów Plateau. The total area of the CDs bottoms is 7.26 $\mathrm{km}^{2}$, representing $1.46 \%$ of the study area. CDs are not evenly distributed in the studied region. In some places, their density reaches $1 \mathrm{CD} \cdot \mathrm{ha}^{-1}\left(\max .1 .9 \mathrm{CDs} \cdot \mathrm{ha}^{-1}\right)$. Areas where CDs density does not exceed 1 CD $h^{-1}$ predominate in the Nałęczów Plateau (Figure 4). Fossil soils and colluvial sediments in 5 CDs were studied in detail and dated (Kołodyńska-Gawrysiak et al., 2017; Kołodyńska-Gawrysiak, Poesen \& Gawrysiak, 2018; Kołodyńska-Gawrysiak, 2019). These CDs are all filled with a 80-90 cm thick Holocene soil-sediment sequence, consisting of two colluvial sediment layers (C1 and C2) and a fossil Colluvisol (S2) Ab2g-Cg (Table 1, Figure 3). This sequence overlies a fossil soil (S1) Ab1g-Bht-Btg-BtC-C that developed on loess in situ. On the slopes this soil has the horizons A-E-Bt1-Bt2-BtC-C-C $\mathrm{HCl}+$ or predominantly A-Bt1Bt2-BtC-C- $\mathrm{C}_{\mathrm{HCl}}+$ as a result of soil erosion (Figure 3). Calcareous loess was found below the soil surface of the CD slopes (Figure 3). Below the CD bottoms, calcareous loess was not detected. The dating results indicate that fossil soil S1 developed during along period from the Late Vistulian until the Late Boreal or

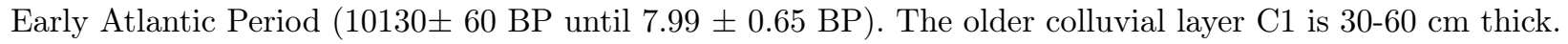
The formation of this layer occurred from the Late Boreal or Early Atlantic Period until the (Middle)Late Bronze Age or Early Iron Age (7.99 $\pm 0.65 \mathrm{BP}$ until $3.67 \pm 0.33 \mathrm{BP} / 2.37 \pm 0.13 \mathrm{BP})$. The fossil Colluvisol (S2) Ab2g-Cg developed on the oldest colluvial layer C1 (Figure 3). This fossil Colluvisol developed from the Late Bronze Age or Early Iron Age until the Early or High Middle Ages $(3.67 \pm 0.33 \mathrm{BP} / 2.37 \pm 0.13 \mathrm{BP}$ until $7^{\text {th }}-8^{\text {th }} \mathrm{c} / 12^{\text {th }}-14^{\text {th }} \mathrm{c}$ ). At the top of the CDs infilling younger colluvia $\mathrm{C} 2,50-70 \mathrm{~cm}$ thick with Colluvisol have been found (Table 1, Figure 3). The younger colluvia C2 layers were deposited during the last several hundred years, i.e. since the Early Middle Ages until today $\left(7^{\text {th }}-8^{\text {th }}\right.$ c until today) (Kołodyńska-Gawrysiak, 2019).

\subsection{SOC content in closed depressions}

In the soils and sediments from the CDs bottoms one can observe higher SOC contents than in the thin soil cover on the slopes of the studied CDs (Figure 5). Both in the bottoms and on the slopes of the CDs, SOC content decreases to $0.2 \%$ with increasing depth (Figure 5). On the slopes of the CDs this value is reached at $0.5 \mathrm{~m}$ depth. After a slight increase in the B horizons, the average SOC content decreases again to $0.2 \%$ already at a depth of $1.3 \mathrm{~m}$ (Figure 5). In the bottom of the CDs, down to a depth of ca. $1 \mathrm{~m}$, a colluvial layer is observed where the average SOC content is the highest, ranging from $0.5 \%$ to $1.1 \%$. With increasing depth, the average SOC content drops to about $0.2 \%$ at a depth of $2 \mathrm{~m}$ (Figure 5 ). A slight increase of SOC content to $0.6 \%$ at a depth of $1.2-1.4 \mathrm{~m}$ accompanies the humus horizons of fossil soils (Figure 5).

Mean SOC content in colluvial sediments C1 and C2 infilling the studied CDs ranges from 0.47 to $0.82 \%$ (Table 2). However in younger colluvial sediments C2 usually is up to twice the value of SOC content from the older colluvial sediments C1. Fossil soils S1 have a smaller SOC content than that of colluvial sediments i.e. $0.2-0.55 \%$ (Table 2 ).

Volume of colluvial sediments in particular CDs varies between 509.6 and $1715.59 \mathrm{~m}^{3}$ and depends on the CD size. The mass of colluvial sediments infilling the studied CDs ranges from 787.52 to 2651.5 t. The SOC content in these colluvial sediments ranges from 5.28 to 20.39 t (Table 2). SOC content in fossil soils S1 covering the original bottoms of the CDs varies from 4.12 to $15.98 \mathrm{t}$ and is smaller than SOC content in colluvial sediments (Table 2). There may be two reasons for this: longer time for decomposition of organic 
matter in these Late Vistulian-Early Holocene soils than in colluvial sediments as well as the areal extent of these soils and of the colluvial sediments in the CDs. In total, between 11.66 and $31.79 \mathrm{t} \mathrm{SOC}$ are stored in the studied CDs, the average being about 20 t SOC (20.62) per CD (Table 2).

Between 206.73 and $178.96 \mathrm{Mg} \mathrm{SOC} \cdot \mathrm{ha}^{-1}(20673.27$ and $17896.01 \mathrm{Mg}$ SOC.km-2) average $192.85 \mathrm{Mg}$ SOC.ha ${ }^{-1}\left(19285.58 \mathrm{Mg}\right.$ SOC. $\mathrm{km}^{-2}$ ) are stored in the bottoms of all CDs (Table 3). Between 1.87 and 7,69 Mg SOC is stored in the topsoil of each CD (Table 4). In regional scale between 42.34 and $34.18 \mathrm{Mg}$ SOC $\cdot \mathrm{ha}^{-1}\left(4234.14\right.$ and $3418.73 \mathrm{Mg} \mathrm{SOC} \cdot \mathrm{km}^{-2}$ ) and average slightly more than $38.26 \mathrm{Mg}$ SOC.ha ${ }^{-1}(3826.44$ $\left.\mathrm{Mg} \mathrm{SOC} \cdot \mathrm{km}^{-2}\right)$ (about $\left.1 / 4\right)$ are stored in the topsoil of all CDs whose total area is slightly over $7 \mathrm{~km}^{2}(1.46 \%$ of the region's area) (Table 5). This shows that in the bottoms of the CDs, the highest SOC reserves are below the topsoil. This is opposite to the situation on the loess plateaus and slopes (Table 6).

\subsection{SOC content in the eroded loess plateau and slopes of Nałęczów Plateau}

The plateau tops and slopes of the Nałęczów Plateau are covered by Luvisols in different stages of erosion (Table 6), which leads to a variation in the depth of the soil profile and of soil properties. In the light of studies on Luvisols conducted by Paluszek (2001) and Paluszek and Żembrowski (2008), the mean thickness of the soil cover on the loess plateau tops and soils is $0.81 \mathrm{~m}$, while the mean SOC content in these soils is 0.79\% (Table 6). On average, $4695432.62 \mathrm{Mg} \mathrm{SOC} \mathrm{(10} \mathrm{238.39} \mathrm{Mg} \mathrm{SOC} \cdot \mathrm{km}^{-2}, 102.38 \mathrm{Mg}$ SOC.ha ${ }^{-1}$ ) of SOC is stored in the soil cover of the slopes and plateau tops (Table 7). Out of that amount, half of the SOC (51.07 Mg SOC.ha ${ }^{-1}, 5107.19 \mathrm{Mg}$ SOC $\cdot \mathrm{km}^{-2}$ ) is stored in the topsoil (average $0-0.24 \mathrm{~m} \mathrm{depth}$ ) of the slopes and plateau tops of the Nałęczów Plateau.

\subsection{The spatial distribution of SOC stocks in the agriculturally used eroded loess landscape of the Nałęczów Plateau}

At regional scale, a strong variation of SOC distribution within non-valley areas can be observed (Figure 6), which results from the presence of a microtopography (closed depressions) on the loess plateau. In most nonvalley areas of the Nałęczów Plateau, SOC storage is 100-105 Mg.ha-1 (Figure 6). The CDs within the loess plateau tops constitute local stores of sediments and SOC originating from soil erosion in their catchment. The CDs are not evenly distributed (see Figure 4), and their presence leads to a local increase in SOC storage within the plateau tops and slopes to more than $105 \mathrm{Mg} \cdot \mathrm{ha}^{-1}$ and even more than $120 \mathrm{Mg} \cdot \mathrm{ha}^{-1}(\max$. 144.1 Mg. $\mathrm{ha}^{-1}$ ) and to a considerable variation of its spatial distribution (Figure 4 and 6 ). A high density of

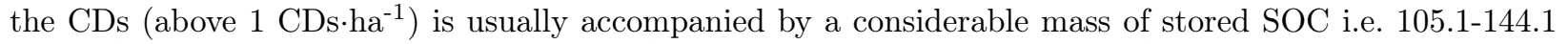
$\mathrm{Mg} \cdot \mathrm{ha}^{-1}$. In these areas about $10-50 \mathrm{Mg} \cdot \mathrm{ha}^{-1}$ and sometimes above $50 \mathrm{Mg} \cdot \mathrm{ha}^{-1} \mathrm{SOC}$ is present in the CDs (Fig. 7).A relationship is observed between CDs density on the plateau tops and slopes and SOC enrichment (Figure 8). SOC enrichment is $4-25 \mathrm{Mg} \cdot \mathrm{ha}^{-1}$ in areas with a high density of CDs (i.e. $>1 \mathrm{CDs} \cdot \mathrm{ha}^{-1}$ ). The Pearson's correlation coefficient is 0.57 . Some areas with a smaller density of CDs (i.e. $<1$ CDs.ha ${ }^{-1}$ ) show a similar or higher (max. $42 \mathrm{Mg} \cdot \mathrm{ha}^{-1}$ ) value of SOC enrichment, which is explained by the larger sizes of the CDs observed there (Figure 8). The size of the CDs is of secondary importance, however, because most CDs are of similar size. More than $76 \%$ of the CDs have diameters less than $65 \mathrm{~m}$, and the area of more than $65 \%$ of the CDs does not exceed $1400 \mathrm{~m}^{2}$ (Kołodyńska-Gawrysiak \& Poesen, 2017).

At the regional scale, most of the analyzed plateau and sloping areas $(95.96 \%)$ have a number of CDs that represent a SOC enrichment in the eroded loess landscape by a few percent (up to about 10\%) (Figure 9).

For $3.83 \%$ of the analyzed area of plateau and slopes, SOC stored in the CDs leads to a local SOC enrichment by $10-20 \%$ i.e. $10.1-30 \mathrm{Mg} \cdot \mathrm{ha}^{-1}$ at most, and for $0.32 \%$ of these areas, up to $20-30 \%$ i.e. $30.1-41.8 \mathrm{Mg} \cdot \mathrm{ha}^{-1}$ respectively (Figure 9,10). An average increasing of SOC storage in the studied eroded landscape is $3.08 \%$. A relationship can be observed between CDs density and SOC enrichment (\%) of loess plateau (Figure 11). The Pearson's correlation coefficient is 0.60 . A high density of the CDs (above $1 \mathrm{CDs}^{-h^{-1}}{ }^{\text {) is usually }}$ accompanied by a considerable enrichment of SOC (i.e. 4-20\%). The presence of a small number of large CDs results in a higher SOC enrichment (by up to 20-28\%) for a CDs density less than 1 CD $h^{-1}$

\section{Discussion}


The results show that the SOC content in the whole soil cover of the agriculturally used loess slopes and plateau tops (including microtopography i.e. CDs) of the Nałęczów Plateau is $100-144 \mathrm{Mg} \cdot \mathrm{ha}^{-1}$. If we disregard the specific for loess area microtopography (CDs), this value in the area under study will be slightly lower, i.e. $102.38 \mathrm{Mg} \cdot \mathrm{ha}^{-1}$ of SOC. In eroded sites (loess slopes and plateaus) $51.07 \mathrm{Mg} \cdot \mathrm{ha}^{-1} \mathrm{SOC}$ are stored in the topsoil (i.e. the A horizon, mean depth $0.24 \mathrm{~m}$ ). In depositional sites (i.e. CDs) about $\frac{1}{4}\left(38.26 \mathrm{Mg}\right.$ SOC.ha ${ }^{-1}$ ) of SOC are stored in the topsoil. This confirms the findings of Rumpel and Kögel-Knabner (2011) that high SOC storages may be present below the topsoil and not only within the topsoil. Therefore, more attention should be given to subsoils when assessing SOC stocks. Otherwise, calculated SOC stocks will be strongly underestimated.

For Wallonia, Chartin et al. (2016) determined the mean predicted SOC stock in the topsoil at $59.9 \mathrm{Mg} \mathrm{C} \cdot \mathrm{ha}^{-1}$ in cropland (53.5-107 Mg C.ha ${ }^{-1}$ for different regions). For the same region, Lettens et al. (2005b) determined the mean SOC stock value at $48 \mathrm{Mg} \mathrm{C} \cdot \mathrm{ha}^{-1}$ in cropland. These differences results from the different research methods adopted by the authors. In France, mean SOC stock for cropland is $55.7 \mathrm{Mg} \mathrm{C} \cdot \mathrm{ha}^{-1}$ (Meersmans et al., 2012). At the scale of the whole territory of Belgium, Meersmans et al. (2011) forecasted a SOC stock value of $49.5 \mathrm{Mg} \mathrm{C} \cdot \mathrm{ha}^{-1}$ for cropland. In Poland, the present soil organic carbon stock (SOC) in topsoils for the main soil types range from 36 to $42 \mathrm{Mg} \mathrm{C} \cdot \mathrm{ha}^{-1}$ (Faber et al., 2012). The results of SOC content in topsoil obtained in this study are comparable with the results for other European regions.

In the agriculturally used loess areas subject to erosion, topography has both a direct and an indirect impact on SOC distribution in the landscape. The direct impact consists of the accumulation of SOC-rich colluvial sediments in depressions; these sediments are products of soil erosion on hillslopes (Sorensen et al., 2006). Erosion causes a loss of SOC in topsoils of sloping land and a reduction of their thickness. In the eroded loess landscapes of the Nałęczów Plateau, CDs are SOC pools where soil erosion-derived colluvial sediments of considerable thickness are accumulated. SOC storage in the CDs originates not only from soil erosion in their catchment but also from fossil soils that have been buried by SOC-rich colluvial sediments. Together with the subsurface fossil soils, closed depressions store more (almost twice) SOC (mean $192.85 \mathrm{Mg} \cdot \mathrm{ha}^{-1}$ ) than eroded soils on sloping cropland (mean $102.38 \mathrm{Mg} \cdot \mathrm{ha}^{-1}$ ). These results demonstrate that if one neglects microtopographic features like CDs the true SOC storage will be underestimated.

The study of Grimm et al. (2008) indicated that topographic features explained most of the spatial variability of soil organic carbon content in the topsoil $(0-0.1 \mathrm{~m})$ at the regional scale. In the subsoil $(0.10-0.50 \mathrm{~m})$, SOC distribution was related to soil texture.

The investigations conducted in the Natęczów Plateau indicate that the microtopography has also a significant impact on the vertical distribution of SOC in soil profiles. About $1 / 4\left(38.26 \mathrm{Mg} \cdot \mathrm{ha}^{-1}\right)$ of the mean SOC storage in CDs is found in the topsoil $(0-0.24 \mathrm{~m})$ of these forms (Table 5). Most SOC stored in the CDs occurs in the subsoil and fossil soil (at a depth ca. $1.0 \mathrm{~m}$ ). The topsoil at the loess plateau tops and slopes (without CDs) contains about half $\left(51.07 \mathrm{Mg} \cdot \mathrm{ha}^{-1}\right)$ of the mean amount $\left(102.38 \mathrm{Mg} \cdot \mathrm{ha}^{-1}\right)$ of SOC within the soil cover of these areas (Table 7).

The indirect impact of topography on the spatial SOC distribution in the landscape is linked to its influence on the larger soil moisture contents (and even water logging) within the CDs and hence on SOC storage. This has been confirmed in studies by Meersmans et al. (2011) who demonstrated that, at the catchment scale, a higher SOC content is correlated with soils of waterlogged valley bottoms. The bottoms of CDs are areas with a larger moisture content than the surrounding slopes, which can be deduced from the redoximorphic features in colluvial sediments deposited in the CD bottoms. The SOC mass stored in the colluvial sediments of the CDs is similar to that of the underlying fossil soils. On average, 10.23 Mg SOC per CD is stored in the colluvial sediments of the studied CDs, while $10.39 \mathrm{Mg}$ SOC per CD is stored in the underlying fossil soils (Table 2). Furthermore, SOC distribution in fossil soil profiles indicates a vertical leaching of SOC deeper into the soil profiles as a result of surface water infiltration in the CD bottom. This is deduced from the morphology and micromorphology of the soils in the CDs and their geochemical properties (KołodyńskaGawrysiak et al., 2017). The indirect impact of topography on SOC storage, expressed by the topographic wetness index (TWI), was emphasized by Wiesmeier et al. (2013). Depressed areas display on average 
a larger soil moisture content which delays the decomposition of organic matter and is conducive to the accumulation of SOC.

According to Wiesmeier et al. (2019), the influence of topography (topographic position, slope gradient, TWI) on the variation of SOC storage is significant only at a local scale. It is less significant at regional scale where SOC storage is determined by climate, vegetation, texture, parent material, land use and management. Models predicting SOC content at the national or large regional scale usually do not take topography into account either. The model of SOC prediction at the national scale, proposed by Martin et al. (2010) showed that SOC distribution is strongly correlated with land use (forest soils, cropland soils). This study reveals the significant impact of (micro)topography (microrelief) on the SOC storage for the regional scale. For the Nałęczów Plateau area, the inclusion of microtopographic features (i.e. closed depressions), typical for loess areas, enabled a more accurate estimation of SOC storage. $95.86 \%$ of the studied eroded landscape actually holds to $10 \%$ more SOC than what models excluding SOC storage in CDs would suggest (Fig. 9). For about $4.13 \%$ of these areas, the exclusion of CDs results in an underestimation of SOC storage in the landscape from $10 \%$ to $30 \%$ (Fig. 9).

The presence of thick colluvial sediment layers of different ages in the CDs suggests the influence of these microtopographic landforms on SOC storage in the past (Kołodyńska-Gawrysiak, Poesen \& Gawrysiak, 2018). Today this carbon storage is often not quantified when conducting organic carbon inventories at local or regional scale. A similar remark has been made for buried peatlands that have accumulated significant $\mathrm{C}$ stocks over millennia (Treat et al., 2019).

\section{Conclusions}

The SOC distribution in the soil cover of the eroded loess areas (with CDs) of the Nałęczów Plateau ranges is $100-144 \mathrm{Mg} \cdot \mathrm{ha}^{-1}$.

About 1/4 (38.26 Mg.ha-1) of SOC in CDs are stored in the topsoil of these forms. Most SOC stored in the CDs occurs in the subsoil and fossil soil. If we disregard microtopography the topsoil contains ca. half (51.07 $\mathrm{Mg} \cdot \mathrm{ha}^{-1}$ ) of the total SOC mass present in the soil cover of the eroded plateau tops and slopes.

In the erosional loess landscape of the Nałęczów Plateau, topography directly and indirectly influences SOC distribution in the landscape. The direct influence stems from the redeposition of SOC through soil erosion on the hillslopes and correlative sedimentation in closed depressions. The indirect impact of topography on SOC distribution results from the influence of the larger soil moisture content (and even water logging) in the CDs on SOC storage.

Taking into account these microtopographic features, typical of loess-covered areas, enabled a more accurate calculation of SOC storage and understanding of its spatial distribution. At the scale of the studied region, excluding SOC storage in CDs would result in a $30 \%$ underestimation of SOC.

CDs had also a significant influence on SOC storage in the past, as evidenced by SOC-rich Holocene soilsediment sequences infilling the CDs.

Conflict of Interest Statement : There is no conflict of interest that exists in the submission of this manuscript.

\section{References:}

1. Arrouays, D., Deslais, W., \& Badeau, V. (2001). The carbon content of topsoil and its geographical distribution in france. Soil Use and Management, 17 (1), 7-11.

2. Baisden, W.T., Parfitt, R.L. (2007). Bomb C-14 enrichment indicates decadal C pool in deep soil? Biochemistry , 85, 59-68.

3. Bałaga, K., Maruszczak, H. (1981). Rozwój współczesnego dna doliny Bystrzycy w świetle badań torfów w Zemborzycach k. Lublina (In Polish).Biuletyn LTN, Geografia , 23, $\frac{1}{2}$ Warszawa, 61-66. 
4. Batjes, N.H. (1996). Total carbon and nitrogen in the soils of the world. European Journal of Soil Science 47 (2), 151-163.

5. Bellamy, P.H., Loveland, P.J., Bradley, R.I., Lark, R.M., \& Kirk, G.J.D. (2005). Carbon losses from all soils across England and Wales 1978-2003. Nature, 437 , 245-248.

6. Chartin, C., Stevens, A., Goidts, E., Krüger, I., Carnol, M., van Wesemael, B. (2016). Mapping Soil Organic Carbon stocks and estimating uncertainties at the regional scale following a legacy sampling strategy (Southern Belgium, Wallonia). Geoderma Regional,http://dx.doi.org/10.1016/j.geodrs.2016.12.006.

7. Conrad, O., Bechtel, B., Bock, M., Dietrich, H., Fischer, E., Gerlitz, L., Wehberg, J., Wichmann, V., Boehner, J., (2015). System for Automated Geoscientific Analyses (SAGA) v. 2.1.4. Geosci. Model Dev., 8, 1991-2007, doi:10.5194/gmd-8-1991-2015.

8. Doetterl, S., Berhe, A. A., Nadeu, E., Wang, Z., Sommer, M., \& Fiener, P. (2016). Erosion, deposition and soil carbon: a review of process-level controls, experimental tools and models to address $\mathrm{C}$ cycling in dynamic landscapes. Earth Science Review 154, 102-122.

9. Faber, A., Łopatka, A., Kaczyński, R., Pudełko, R., Kozyra, J., Borzęcka-Walker, M., \& Syp, A. (2012). Assessment of existing soil organic carbon stocks and changes at a national and regional level in Poland. Journal of Food, Agriculture \&3 Environment 10 (3844),1210-1213.

10. Gawrysiak, L., \& Harasimiuk, M. (2012). Spatial diversity of gullies density on Lublin Upland and Roztocze Hills (SE Poland).Annales UMCS, B, 67 (1), 27-43.

11. Grimm, R., Behrens, T., Marker, M., \& Elsenbeer, H. (2008). Soil organic carbon concentrations and stocks on Barro Colorado island- digital soil mapping using random forests analysis. Geoderma 146 (1-2), 102-113.

12. Guidelines for soil descriptions (fourth edition), 2006. Food and Agriculture Organization of the United Nations: Rome, 97pp.

13. Harasimiuk, M. (1980). Structural relief of Lublin Upland and Roztocze (in Polish). UMCS, Lublin, 136 p.

14. Harasimiuk, M. (1987). Lithologic Properties as Indices of the Sedimentation Conditions of the Vistulian Loesses in the Eastern Part of the Nałęczów Plateau (SE Poland). Annales UMCS, sec. B, 41, 11,179-202.

15. Harasimiuk, M., \& Henkiel, A. (1978). The influence of the geological structure and of the substratum relief on the configuration of loess cover in the area of the western part of the Nałęczów Plateau (in Polish with English summary). Annales UMCS, B, 30/31 , 55-80.

16. Hobley, E.U., \& Wilson, B. (2016). The depth distribution of organic carbon in the soils of eastern Australia. Ecosphere 7(1) , 1-21.

17. Jobbágy, E., \& Jackson, R. (2000). The vertical distribution of soilorganic carbon and its relation to climate and vegetation.Ecological Applications 10 , 423-436.

18. Kołodyńska-Gawrysiak, R,. \& Poesen, J. (2016). Closed depressions in the European loess belt - natural or anthropogenic origin? Geomorphology 288, 111-128.

19. Kołodyńska-Gawrysiak, R., Chodorowski, J., Mroczek, P., Plak, A., Kiebała, A., Zgłobicki, W., Trzciński, J., \& Standzikowski K. (2017). The impact of natural and anthropogenic processes on the evolution of closed depressions in loess areas. A multi-proxy case study from Nałęczów Plateau, Eastern Poland. Catena 149, 1-18, doi: http://dx.doi.org/10.1016/j.catena.2016.07.029.

20. Kołodyńska-Gawrysiak, R., Poesen, J., \& Gawrysiak, L. (2018). Assessment of long-term Holocene soil erosion rates in Polish loess areas using sedimentary archives from closed depressions. Earth Surface Processes and Landforms 43, 978-1000, doi: 10.1002/esp.4296. 
21. Kołodyńska-Gawrysiak, R. (2019). Holocene evolution of closed depressions and its relation to landscape dynamics in the loess areas of Poland. The Holocene 29, 4, 543-564, doi: 10.1177/0959683618824792.

22. Kurczyński, Z., Stojek, E., Cisło-Lesicka, U. (2015). GUGiK tasks carried out under the ISOK project. (In:) Handbook for training participants using products LiDAR (In Polish). GUGiK, Warszawa, 22-58

23. Lal, R. (2004). Soil carbon sequestration to mitigate climate change. Geoderma 123 (1-2) , 1-22.

24. Lettens, S., Van Orshoven, J., van Wesemael, B., De Vos, B., \& Muys, B. (2005a). Stocks and fluxes of soil organic carbon for landscape units in Belgium derived from heterogeneous data sets for 1990 and 2000. Geoderma, 127, 11-23.

25. Lettens, S., Van Orshoven, J., Van Wesemael, B., Muys, B., \& Perrin, D. (2005b). Soil organic carbon changes in landscape units of Belgium between 1960 and 2000 with reference to 1990. Global Change Biology 11 (12), 2128-2140.

26. Lo Seen, D., Ramesh, B.R., Nair, K.M., Martin, M., Arrouays, D., \& Bourgeon, G. (2010). Soil carbon stocks, deforestation and land cover changes in the western ghats biodiversity hotspot (India). Global Change Biology 16 (6), 1777-1792.

27. Martin, M. P., Orton, T.G., Lacarce E., Meersmans, J., Saby, N.P.A., Paroissien, J.B., Jolivet, C., Boulonne, L., \& Arrouays, D. (2014). Evaluation of modelling approaches for predicting the spatial distribution of soil organic carbon stocks at the national scale.Geoderma, 223-225, 97-107.

28. Martin, M.P., Wattenbach, M., Smith, P., Meersmans, J., Jolivet, C., Boulonne, L., \& Arrouays, D. (2010). Spatial distribution of soil organic carbon stocks in France. Biogeosciences Discussion 7,8409-8443, doi:10.5194/bgd-7-8409-2010.

29. Maruszczak, H. (1991). Stratigraphical differentation of Polish Loesses. (In:) Maruszczak, H. (ed.) Main sections of loesses in Poland. Lublin.

30. Meersmans, J., De Ridder, F., Canters, F., De Baets, S., \& Van Molle, M. (2008). A multiple regression approach to assess the spatial distribution of soil organic carbon (SOC) at the regional scale (Flanders, Belgium). Geoderma 143 (1-2), 1-13.

31. Meersmans, J., Van Wesemael, B., De Ridder, F., Fallas Dotti, M., De Baets, S., \& Van Molle, M. (2009). Changes in organic carbon distribution with depth in agricultural soils in northern Belgium, 19602006. Global Change Biology, doi: 10.1111/j.1365-2486.2009.01855.x.

32. Meersmans, J., vanWesemael, B., Goidts, E., vanMolle,M., De Baets, S., \& De Ridder, F. (2011). Spatial analysis of soil organic carbon evolution in Belgian croplands and grasslands, 1960-2006. Global Change Biology 17, 466-479.

33. Meersmans, J., Martin, P.M., Lacarce, E., De Baets, S., Jolivet, C., Boulonne, L., Lehmann, S., Saby, N.P.A., Bispo, A., \& Arrouays, D. (2012). A high resolution map of French soil organic carbon.Agronomy for Sustainable Development 32, 841-851.

34. Meersmans, J., Arrouays, D., Van Rompaey, A.J.J., Pagé, Ch., De Baets, S., \& Quine, T.A. (2016). Future $\mathrm{C}$ loss in mid-latitude mineral soils: climate change exceeds land use mitigation potential in France.Scientific Reports, 6 : 35798 , doi: 10.1038/srep35798.

35. Munsell Soil Color Charts (1994). Revised edition. Gretag Macbeth, 617 Little Britain Road, New Windsor, NY 12553.

36. Neufeldt, H. (2005). Carbon stocks and sequestration potentials of agricultural soils in the federal state of Baden-Württemberg, SW Germany. Journal of Plant Nutrition and Soil Science 168 (2),202-211.

37. Paluszek, J. (2001). The influence of the position in the relief on the aggregation and water resistance of aggregates colluvial soils on loess (in Polish). Acta Agrophysica, 48, 99-105. 
38. Paluszek, J., \& Żembrowski, W. (2008). Improvement of erodable soils in loess landscapes (in Polish). Acta Agrophisica 164, 4,160 pp.

39. Pignard, G., Dupouey, J.L., Arrouays, D., \& Loustau, D. (2000). Carbon stocks estimates for French forests. Biotechnology, Agronomy, Society and Environment, 4, 285-289.

40. Pożaryska, K. (1967). Cretaceous-Tertiary transition beds in Poland (except for the Carpathians) (in Polish with English summary). Geological Quarterly, 11 (3), 661-672.

41. Pożaryski, W., Maruszczak, H., Lindner, L. (1994). Chronostratigraphy of Pleistocene deposits and evolution of the Middle Vistula River Valley with particular attention to the gap through the South Polish Uplands (in Polish with English summary). Prace Państwowego Instytutu Geologicznego, 147, 1-58.

42. Rumpel, C., \& Kögel-Knabner, I., (2011). Deep soil organic matter-a key but poorly understood component of terrestrial C cycle. Plant Soil 338, 143-158.

43. Seibert, J., Stendahl, J., \& Sorensen, R. (2007). Topographical influences on soil properties in boreal forests. Geoderma 141 (1-2), 139-148.

44. Sorensen, R., Zinko, U., \& Seibert, J. (2006). On the calculation of the topographic wetness index: evaluation of different methods based on field observations. Hydrology and Earth System Sciences, 10 (1), $101-112$.

45. Superson, J., Jezierski, W., \& Król, T. (2003). Impact of deforestation of the Nałęczów Plateau on the development of sediments of the Bystra valley bottom (In:) Waga, M., Kocel, K. (eds). Man in the natural environment - record of activity (In Polish). Sosnowiec, 207-212.

46. Superson, J., Rodzik, J., Reder, J., Zgłobicki, W., Klimowicz, Z., \& Franczak, Ł. (2016). Phases of alluvial fan development in a loess area, Lublin Upland, E Poland. Quaternary International 399,31-45.

47. Suuster, E., Ritz, C., Roostalu, H., Kolli, R., \& Astover, A. (2012). Modelling soil organic carbon concentration of mineral soils in arable land using legacy soil data. European Journal of Soil Science 63 (3) , 351-359.

48. Tan, Z.X., Lal, R., Smeck, N.E., \& Calhoun, F.G. (2004). Relationships between surface soil organic carbon pool and site variables. Geoderma 121 (3-4), 187-195.

49. Thompson, J.A., Pena-Yewtukhiw, E.M., \& Grove, J.H. (2006). Soil-landscape modeling across a physiographic region:Topographic patterns and model transportability. Geoderma 133 , 57-70.

50. Treat, C.C., Kleinen, T., Broothaerts, N., Dalton, A.S., Dommain, R., Douglas, T.A., Drexler, J.Z., Finkelstein, S.A., Grosse, G., Hope, G., Hutchings, J. Jones, M.C., Kuhry, P., Lacourse, T., Lähteenoja, O., Loisel, J., Notebaert, B., Payne, R. J., Peteet, D.M., Britta, A., Sannel, K., Stelling, J.M., Strauss, J., Swindles, G.T., Talbot, J., Tarnocai, Ch., Verstraeten, G., Williams, Ch.J., Xia, Z., Yu, Z., Väliranta, M., Hättestrand, M., Alexanderson, H., \& Brovkin, V. (2019). Widespread global peatland establishment and persistence over the last 130,000 y. www.pnas.org/cgi/doi/10.1073/pnas.1813305116.

51. Urban, D., \& Mikosz, A. (1996). Changes of plant cover in the Ciemięga River valley and its surrounding in the vicinity of Ożarów in Holocene. (In:) Puszkar, T. \& Puszkar, L. (eds) Contemporary trends in ecology. Behavioral Ecology (In Polish). Lublin, 211-222.

52. Van Wesemael, B., Lettens, S., Roelandt, C., \& Van Orshoven, J. (2005). Modelling the evolution of regional carbon stocks in Belgian cropland soils. Canadian Journal of Soil Science, 85, 511-521.

53. Vos, C., Don, A., Hobley, E.U., Prietz, R., Heidkamp, A., \& Freibauer, A. (2019). Factors controlling the variation in organic carbon stocks in agricultural soils of Germany. European Journal of Soil Science , 70, $550-564$ 
54. Wiesmeier, M., Hübner, R., Barthold, F., Spörlein, P., Geuß, U., Hangen, E., Reischl, A., Schilling, B., von Lützow, M., \& Kögel-Knabner, I. (2013). Amount, distribution and driving factors of soil organic carbon and nitrogen in cropland and grassland soils of southeast Germany (Bavaria). Agriculture, Ecosystems $8 \mathcal{G}$ Environment 176, 39-52.

55. Wiesmeier, M., Barthold, F., Spörlein, P., Geuß, U., Hangen, E., Angst, G., Reischl, A., Schilling, B., von Lützow, M., \& Kögel-Knabner, I. (2014). Estimation of totalorganic carbon storage and its driving factors in soils of Bavaria(southeast Germany). Geoderma Regional1 , 67-78.

56. Wiesmeier, M., Urbanski, L., Hobley, E., Lang, B., von Lützow, M., Marin-Spiotta, E., van Wesemael, B., Rabot, E., Ließ, M., Garcia-Franco, N., Wollschläger, U., Vogel, H-J., \& Kögel-Knabner, I. (2019). Soil organic carbon storage as a key function of soils - A review of drivers and indicators at various scales. Geoderma 333, 149-162.

57. Woźniak, P. (2015). High Resolution Elevation Data in Poland (In:) Jasiewicz, Z., Zwoliński, Z., Mitasova, H. \& Hengl, T. (ed.).Geomorphometry for Geoscience. Ministry of Science and High Education of Poland, Adam Mickiewicz University in Poland, 13-14.

List of tables:

Table 1. Description of soil horizons and colluvial layers (sediments) deposited in CDs. Soil profile pits were dug in the deepest point of the CDs

Table 2. Characteristics of fossil soil horizons and colluvial layers analysed for the calculation of SOC content in closed depressions (CDs). Standard deviation of mean SOC (t) in CDs is $7.42 \mathrm{t}$

Table 3. Calculation of SOC stored in all $5367 \mathrm{CDs}$ detected in the study area $\left(496.08 \mathrm{~km}^{2}\right)$. ${ }^{*}$ for reference see table $2{ }^{* *}$ standard deviation is 7.421

Table 4. SOC stored in the topsoils of the CDs in the study area. ${ }^{*}$ for reference see Table $1,{ }^{*}$ for reference see Table 2

Table 5. Calculation of SOC stored in topsoil of all 5367 CDs detected in the study area $\left(496.08 \mathrm{~km}^{2}\right)$. ${ }^{*}$ for reference see table $4,{ }^{* *}$ standard deviation is 2.18

Table 6. Properties of Luvisols (mean values from 6 pedons) of the Nałęczów Plateau

(based on Paluszek 2001, 2008)

Table 7. SOC content in soils on the plateau and slopes of the Nałęczów Plateau (based on Paluszek 2001, 2008). * mean thickness of A horizon (see Table 6), ${ }^{* *}$ mean SOC (\%) in A horizon (see Table 6 )

List of figures:

Figure 1. Location of the Nałęczów Plateau

Figure 2. Typical CD infilled by a Holocene soil-sediment sequence in loess landscape of Nałęczów Plateau

Figure 3. Typical CD, studied in Rąblów, a) location of the outcrops (soil profile pits) and drillings along two transects, b) stratigraphy and soil horizons in $\mathrm{CD}, \mathrm{c}$ ) cross-sectional structure of the CD

Figure 4. Spatial distribution of CDs per unit area in the studies region. A unit area (hexagon) covers 10 ha

Figure 5. SOC content in the studied closed depressions (CDs)

Figure 6. Spatial distribution of SOC in the eroded loess landscape of the Nałęczów Plateau. River valleys and main dry valleys were excluded in these calculations

Figure 7. SOC from CDs in loess landscape

Figure 8. Relationship between CDs density and SOC enrichment $\left(\mathrm{Mg}_{\mathrm{g}} \mathrm{ha}^{-1}\right)$. Calculation is based on 1791 polygons (10 ha in size), where CDs and loess plateau and slopes cover $100 \%$ of polygon. 
Figure 9. Contribution of SOC stored in CDs (SOC enrichment in \%) to overall SOC distribution in loess landscape

Figure 10. Contribution of SOC stored in CDs (SOC enrichment in $\mathrm{Mg} \cdot \mathrm{ha}^{-1}$ ) to overall SOC distribution in the studied loess landscape.

Figure 11. Relationship between CDs density and SOC enrichment (\%) in loess landscape (calculation is based on the same polygons as in Figure 7). Total number of datapoints corresponds to 1791 polygons (10 ha in size).
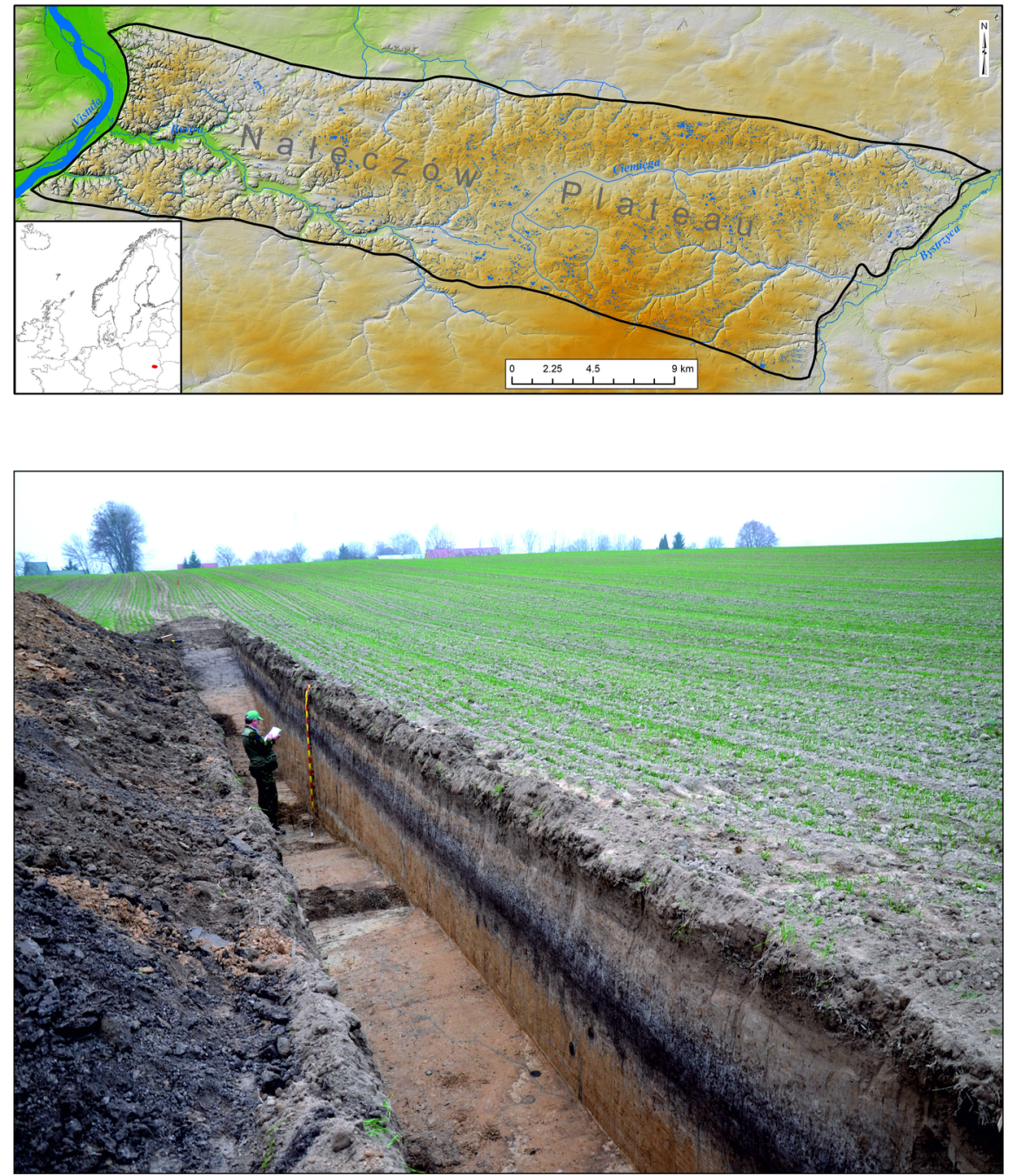

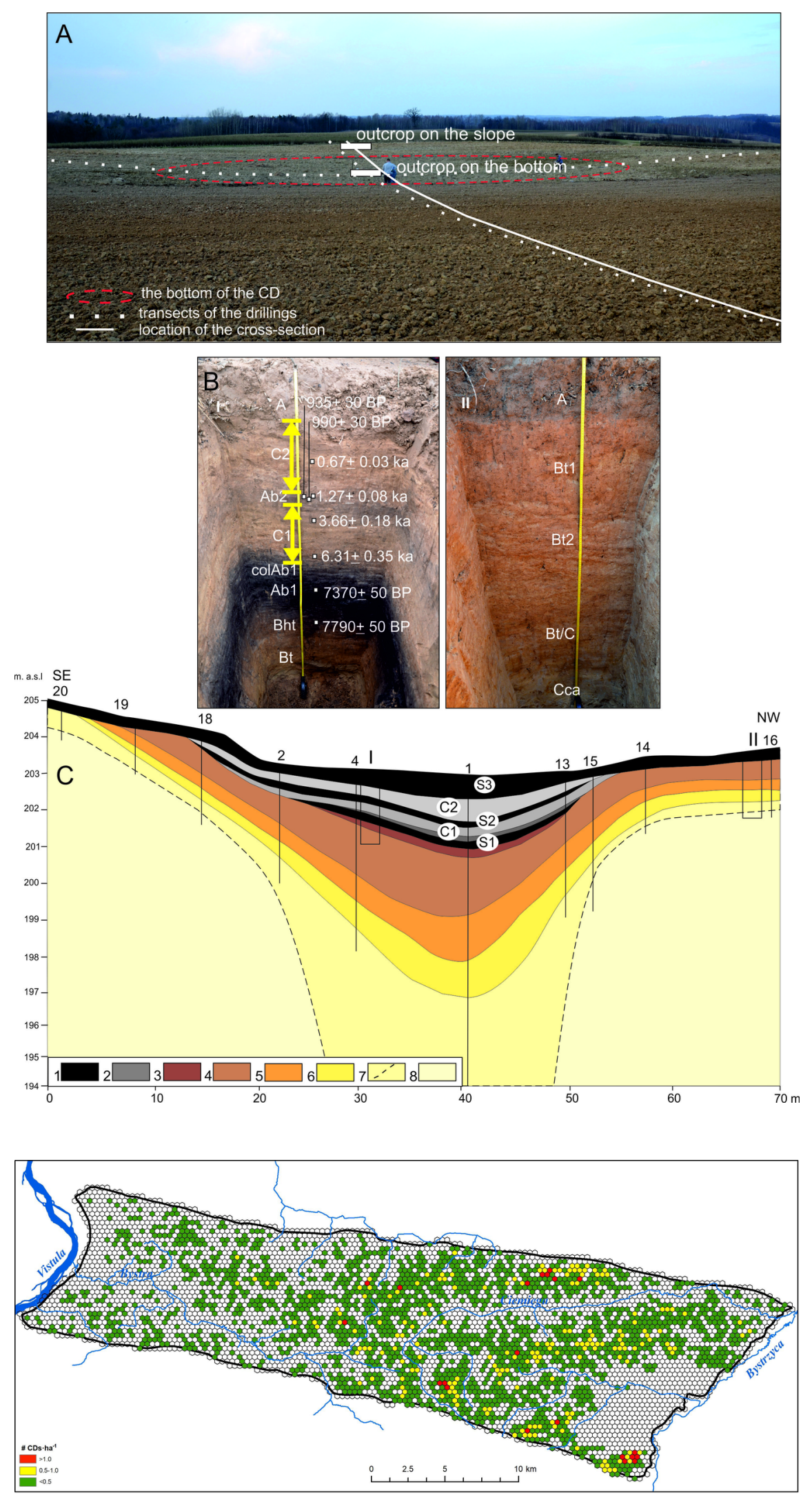

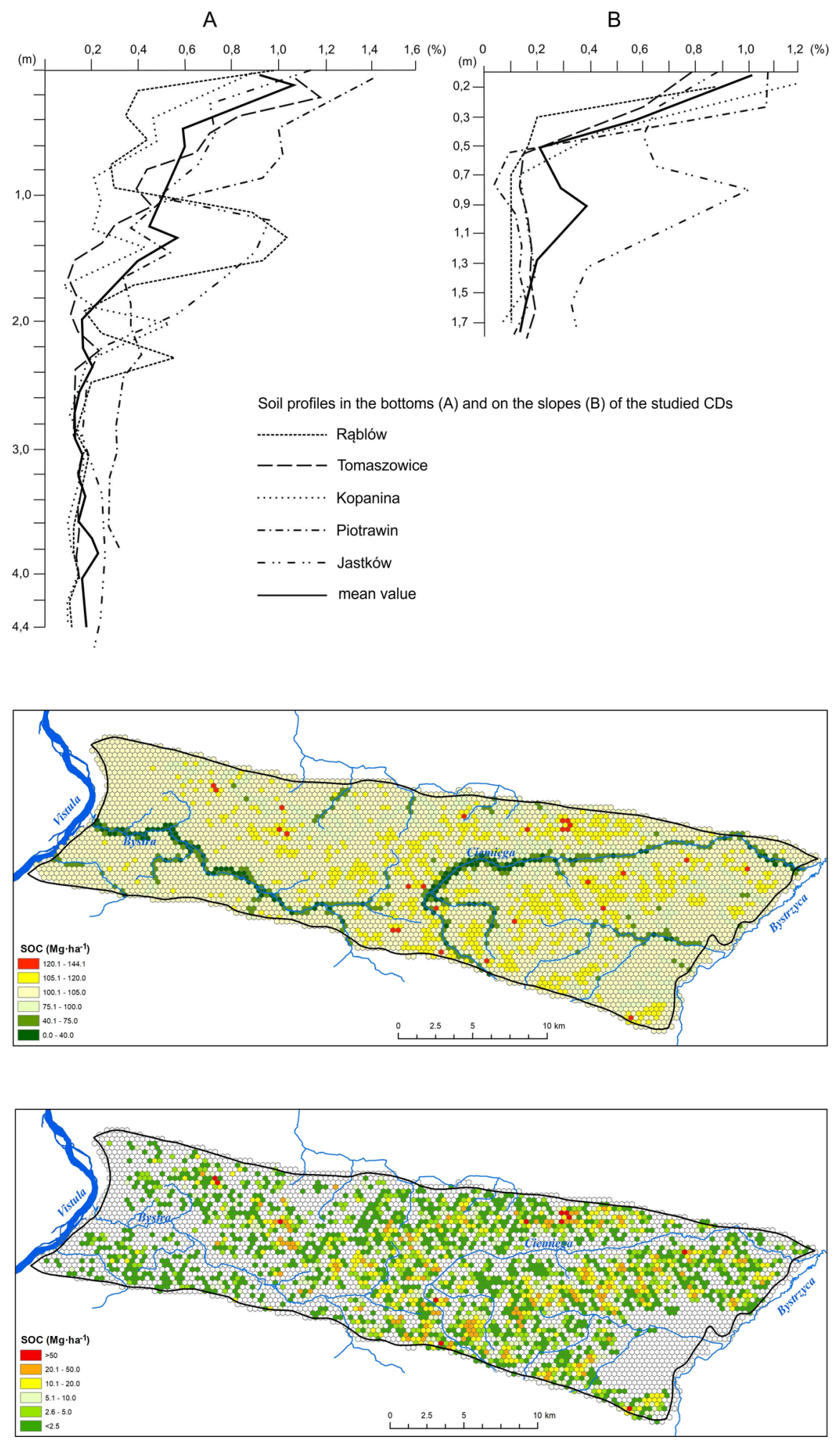

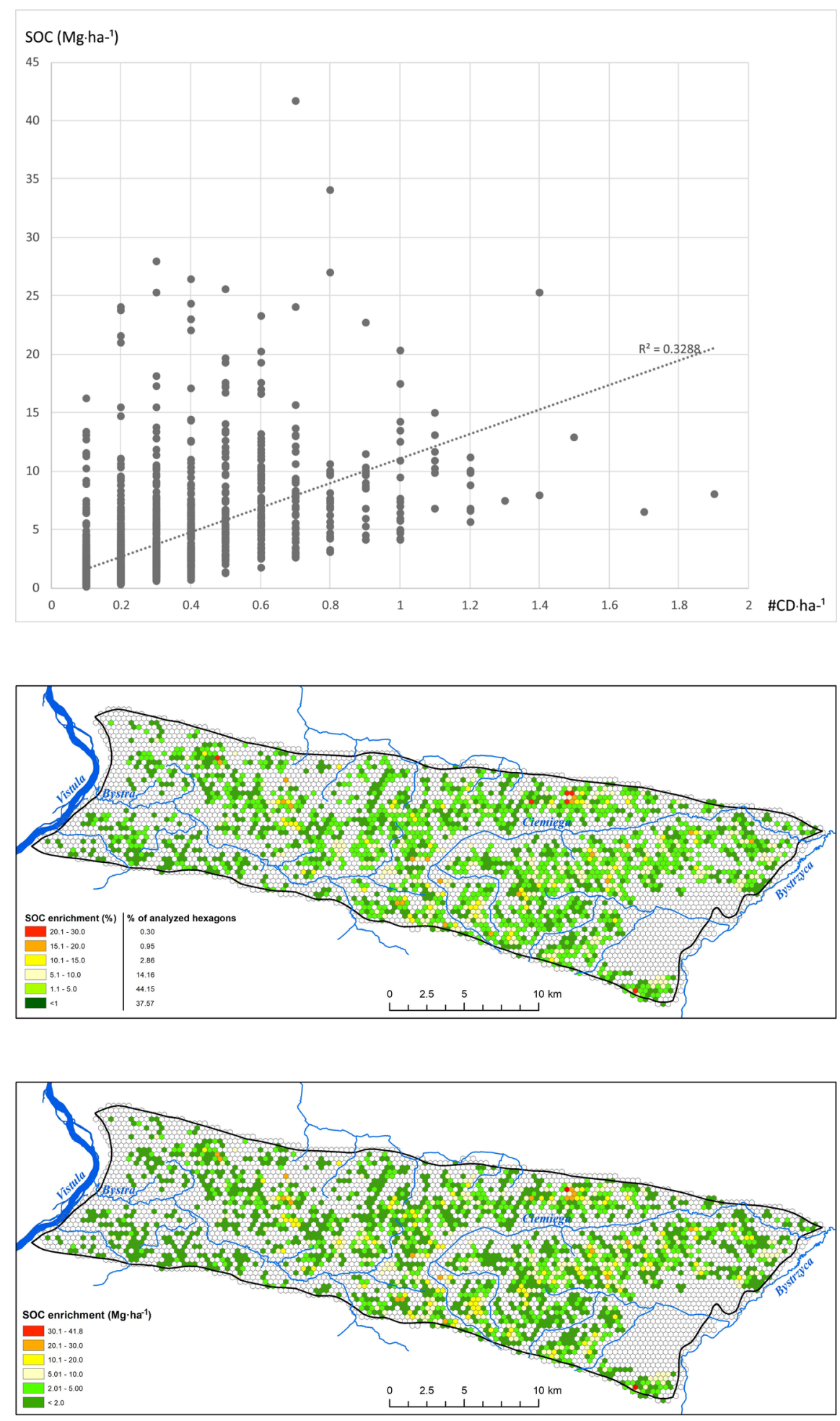


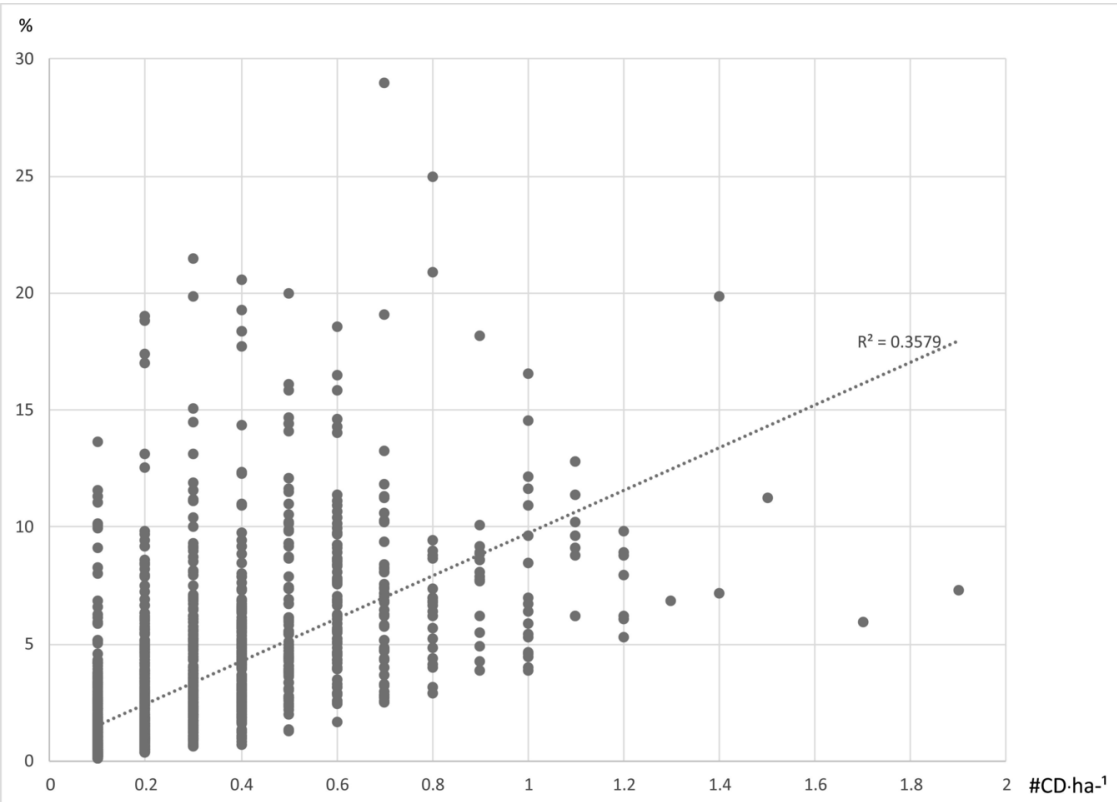

